\title{
Testing the Club Dynamics of the BRICS: The New Development Bank from Conception to Establishment
}

\author{
A.F. Cooper, A.B. Farooq
}

\begin{abstract}
Andrew F. Cooper - Professor, Department of Political Science and Balsillie School of International Affairs at the University of Waterloo, Director, Centre for the Study on Rapid Global Change at the University of Waterloo; 200 University Avenue West, Waterloo, ON N2L 3G1, Canada; E-mail: acooper@uwaterloo.ca

Asif B. Farooq - Doctoral student, Department of Political Science, University of Toronto, Researcher, Centre for the Study on Rapid Global Change at the University of Waterloo; 100 St. George Street, Toronto, ON M5S 3G3, Canada; E-mail: asif.farooq@mail.utoronto.ca

The article addresses the puzzle of how the BRICS members were able to overcome institutional constraints and establish the New Development Bank (NDB) in a short period after its conception. It argues that the club dynamics among the members help them circumvent internal conflicts due to the embedded mutual common interest in status attribution. The dynamics also create an informal institutional platform for them to manoeuvre through intra-BRICS competitive interests by taking a symbolic stake in the NDB's development. Club diplomacy downplays contentious issues while elevating and reinforcing issues of common interest. Such an approach is tested, however, when the focus shifts from externalized demands to collective action. Calls for reforming the global system notably through a more equitable distribution of voice and influence in the International Monetary Fund and the World Bank further consolidated the club-like culture among the BRICS members. At the same time, the push for a bold initiative of their own, such as the establishment of a development bank with the promise of massive infrastructure investment targeted at other countries in the global South, demonstrated the symbolic need to move beyond the status quo.
\end{abstract}

Key words: BRICS, New Development Bank, club dynamics, multilateralism, institutionalism

\section{Introduction}

The BRICS countries of Brazil, Russia, India, China and South Africa made a significant progress with the creation of the New Development Bank (NDB) and cemented the group's institutional link among its members. Since this initiative was first brought to the fore, by India at the 2011 New Delhi Summit, there was scepticism about the capacity of the BRICS members to deliver on the proposal, not only because of broad differences in strategic interests but also due to the lack of institutional capacity to navigate those differences. Yet the BRICS countries were able to translate an ideational concept of how to booster infrastructure development needs into delivery of the NDB at the 2014 Fortaleza Summit in Brazil, with an initial $\$ 50$ billion fund with each member having an equal stake. Furthermore, the BRICS also agreed to establish a currency reserve agreement, amounting to $\$ 100$ billion to deal with any future financial crisis.

Still, despite this progress, the BRICS's ability to overcome the obstacles to establishing the NDB remains a puzzle. First, it is surprising that a group of countries can cooperate in such an important area when their broader interests as regional powers and aspirations as global powers are highly competitive. Indeed, at the geopolitical level, tension between two members - 
China and India - had recently escalated due to a sensitive border dispute over which they fought in the early 1960s. More generally, both countries actively balance power in the region by playing off each other's neighbours. Although the economic incentives for expanding infrastructure investment in India, Brazil and South Africa helps explain why these countries were able to cooperate multilaterally via the BRICS, they provide little insight into how such cooperation is possible in the presence of mutually diverging interests. Furthermore, the normative divide among the BRICS members is also salient enough to raise questions about the degree and sustainability of their cooperation on economic affairs that overlooks their sociopolitical differences.

Second, multilateralism as a mechanism for providing development assistance appears to be less attractive than the greater foreign policy gain that could be achieved through bilateral means. This bias is even more prevalent for emerging donors such as the BRICS members because they are already using their scarce resources in providing development assistance in the form of concessional and non-concessional loans and credits. A strong cluster of members has already made great strides in a short period in reaching out to many countries in the global South. If the NDB eventually starts lending beyond the club of five - still a divisive issue within the BRICS - then foreign policy gains that could have been achieved through bilateral cooperation would be diminished for the individual BRICS countries.

In such circumstances, it is worthwhile to examine from a multilateral perspective how BRICS members have overcome these formidable constraints. What factors helped them deal with the institutional hurdles in establishing the NDB? Using this form of multilateralism in terms of a club model and taking a conceptual and empirical approach, this article argues that club dynamics help explain how the BRICS members circumvented significant barriers to establish the NDB.

\section{Circumventing Barriers through Club Means}

According to John Ruggie, "multilateralism" modifies the noun "institution." Institutions are stable sets of constitutive, regulative and procedural norms and rules, formal and informal that "prescribe behavioural roles, constraint activity, and shape expectations" [Keohane, 1990, p. 732]. Ruggie [1992] argues that multilateralism is a form of institutional behaviour among two or more states on the basis of generalized principles of conduct. States often delegate tasks to a third party agent through modes of multilateralism. Multilateral institutions could be formal or informal self-selective institutions such as the United Nations, the G20, the Association of Southeast Asian Nations, the World Bank, the International Monetary Fund (IMF) and Bank for International Settlements. There are benefits to working through multilateral institutions and delegating tasks to these forums [Keohane, Macedo and Moravcsik, 2009]. However, there are also drawbacks, in what Michael Barnett and Martha Finnemore [1999, p. 719] refer to as dysfunctional pathological behaviour embodied in the "irrationality of rationalization, universalism, normalization of deviance, organizational insulation, and cultural contestation." Taking a principal-agent approach, Daniel Nielson and Michael Tierney [2003] further articulate the state's potential for loss of control over multilateral institutions when tasks are delegated to them by states.

On the issue of official development assistance (ODA), in terms of a specific functional area, states should have little interest in participating in multilateralism as they are likely to achieve foreign policy gain more through bilateral means. Externally, states gain from bilateral ODA as it can influence recipient country's policy choices in favour of the donor country [Baldwin, 1985]. Bilateral ODA also helps garner domestic lawmakers' support as they main- 
tain stronger control. Many major donors underperform in their support for development assistance compared to public support, e.g., Canada and Australia, and many are wary of public opinion and thus reduce assistance when support is low during the economic hard times, e.g., the United States [Otter, 2003]. Furthermore, public opinion tends to take a cautious approach on ODA through multilateral institutions in spite of acknowledging its benefit [Milner and Tingley, 2013].

Nevertheless, scholars have studied why states still participate in multilateral institutions despite the drawbacks [Balogh, 1967; Easterly and Pfutze, 2008; Hawkins, Lake, Nielson et al., 2006; Ikenberry, 2001; Koremenos, Lipson and Snidal, 2001; Ruggie, 1993]. Many argue that ODA through multilateral means could be more effective and thus has an advantage over bilateral means. However, this argument misses the conceptual clarity that explains the multilateral institutional initiatives by the emerging countries - notably the BRICS countries - with competing and diverging interests and aspirations. Their differences not only create a "trust deficit" but also challenge any cooperation and coordination that could be sustained in the long term. Economic growth is uneven among the BRICS members [Sharma, 2012]. Despite policy cohesion on some fronts, BRICS members still struggle to operate as a strong coalition [Brütsch and Papa, 2013]. Although the common foreign policy interests among them cannot be underestimated on the issue of sovereignty, the voting patterns of BRICS members in the UN also demonstrates diverging interests in foreign policy [Ferdinand, 2014].

Intra-BRICS friction is evident in members' regional aspirations too. Economic growth will help them expand their military and economic capabilities, challenging the order and stability of the international system [Brawley, 2007]. But their emerging power status contains embedded competition, which in many ways amplifies the arguments of the realists. As John J. Mearsheimer [1994/95] argues, when states are always vying for relative gains, it is theoretically impossible for them to cooperate. The trust deficit due to national security interests will always discourage states from cooperating for collective benefit for fear of defection, free riding and troublemakers. This lack of trust is also evident in intra-BRICS security cleavages. China's growing military and diplomatic power is a security threat to India's regional aspirations. Both countries fought a protracted war over a disputed border. The two-week military standoff in Ladakh in 2014 further aggravated relations. Although India's own foreign policy approach has achieved substantive gains, its capabilities are yet to match its rising expectation, let alone match China's diplomatic prowess [Mansingh, 2010]. Huang Yasheng [2011] argues that relations are fraught with more competing issues than their mutually common interests. Brazil, too, is wary of China's growing reach in South America. Brazil's entrepreneurial drive has expanded its diplomatic reach well beyond its region while diffusing its power globally, in keeping up with the diplomatic stretch of emerging powers; but its recent sluggish economy has brought scepticism about its capability [Christensen, 2013]. China's diplomatic prowess and development assistance - what Joshua Kurlantzick [2007] has called China's "charm offensive" - challenge the interests and aspirations of Brazil, India and South Africa on the African continent. Furthermore, despite growing trade among the BRICS members, the trade deficit has been growing in China's favour.

These differences highlight that the fact that while post-colonialism would argue that the BRICS countries have ideological and historical similarities, as all except Russia share a history of colonial subjugation, intra-BRICS solidarity based on South-South rhetoric barely manifest the complexity of their mutual relations. Thus, while post-colonial ideological solidarity may help members develop a common cause with "us versus them" world view, as in the division between the North and the South, it explains little the divisions and uneven economic and political power dynamics within the global South. Moreover, BRICS members also have ideo- 
logical and institutional differences [Armijo, 2007]. Brazil shares characteristics with the South as much as with its Northern partners [Armijo and Burges, 2009]. India, Brazil and South Africa actively exploit their democratic character for soft power. These countries have formed the IBSA Dialogue Forum, which often publicizes its intra-group cohesion based on "common political identity"; in other words, it has democracy as its linchpin [Vieira and Alden, 2011]. The state of democracy in Russia and the one-party Chinese state are in direct contrast to the rest of the BRICS members.

These differences are viewed by many observers as compromising BRICS's members ability to cooperate in a multilateral setting and function as a powerful bloc in advancing a new world order. Sceptics have argued that the BRICS is an over-hyped challenge to the existing power and it is nothing but "Brics without mortar" [Stephens, 2011]. While Yana Leksyutina [2014] argues that the consolidation of the BRICS is a means for China to pave the way to the global economic governance, Michael Glosny [2009] contends the BRICS does not challenge the existing international order. Pang Zhongying [2014], however, takes a conservative position on the influence of the BRICS through its establishment of the NDB. He argues that it is premature to affirm whether NDB is a “挑战”(challenge) or provides “替代” (alternative) to the existing global institutions. Ye Yu [2014] and Chen Zhongtian [2014] argue that the BRICS could improve South-South as well as North-South relations as the NDB supplements the IMF and other development banks. Zhu Jiejin [2014] notes that the NDB is the BRICS's effort for " 内谋发展、外促改革” (“internal development [among BRICS countries] and external reform [in global governance]”). Some also make more nuanced arguments about the ability of the BRICS to challenge the international neoliberal order [Glosny, 2009]. Its inability to represent itself as qualitatively distinct from the hierarchical neoliberal world architecture - although this does reveal a bias within the system - demonstrates the group's internal weakness as a bloc in seriously challenging the traditional powers [Gray and Murphy, 2013].

Despite the challenging dynamics among the BRICS members, they have been able to institutionalize the BRICS as an informal institution, and have demonstrated real progress in formally institutionalizing the NDB. This process opens up questions about how the group as a multilateral informal institution came into existence at the first place. Scholars have mostly advanced arguments such as those adopted by Barbara Koremenos, Charles Lipson and Duncan Snidal [2001], who take a functionalist approach that states construct institutions that reflect their rational and purposive interests. Glosny [2009] argues that China needs the BRICS less than its other members need China. He provides a functional argument for China's cooperation: the BRICS helps minimize members' dependence on the United States, constrain U.S. unilateralism and strengthen South-South solidarity, and the coordination among members provides leverage on international issues. Similarly, Adriana Abdenur [2014, p. 90] writes that, "from a geopolitical point of view, the BRICS helps China to counter US hegemony without direct confrontation." Russia, given the constraints on its ability to withstand US influence unilaterally and despite having interests that compete with China's aspiring power, uses China's rise vis-à-vis western influence to hedge its geopolitical interest in the emergence of the BRICS as an institution [Hancock, 2007; Roberts, 2009]. South Africa's economic weight, continental peacemaking and peacekeeping efforts, and its soft power through programs such as the New Partnership for Africa's Development (NEPAD) are bolstered by the political platform it finds in the BRICS. Chris Alden and Maxi Schoeman [2013, p. 115] write that South Africa's "BRICS membership becomes both proof of its status and an instrument for reinforcing this status." In addition to geopolitical interests, economic incentives offer a functional explanation for members' ability to overcome their mutual differences, and are often advanced as an apt explanation for China and India's cooperation in the BRICS [Rusko and Sasikumar, 2007]. 
Gregory Chin [2014] takes a similar functionalist approach in explaining why the BRICS members have established the NDB despite mutually diverging interests. The established institutions, especially the World Bank and the Asian Development Bank, have not met the infrastructure development needs of the developing world. The governing structure of these institutions is also not changing, as demanded by BRICS members, to reflect the changing balance of global power. Chin further argues that the G20 has also repetitively failed to follow through on the infrastructure investment needs with any meaningful progress - he calls it the G20's mock compliance - at its 2011 French and 2012 Mexican summits after the initial interest expressed at the 2010 Seoul Summit. Therefore, he writes, "it should not be surprising that the BRICS governments turned to creating an alternative institutional option to try to mobilize finance for infrastructure in the developing world" [Chin, 2014, p. 370].

Although these functionalist arguments provide informative explanations of why BRICS members cooperate, they fall short of explaining how they cooperate multilaterally in a way that makes it possible not only to respond to mutually common needs but also to overcome mutually diverging interests. The functionalist approach also does not adequately explain why this particular group of countries has been able to cooperate with each other while excluding others. The club model can provide an insightful glimpse into the inner workings of how the BRICS was able to advance the NDB initiative.

\section{Institutional Constraints to Establishing the NDB}

The establishment of the NDB belies built-in scepticism about the BRICS's institutional capacity to produce real results. What is even more important is that the NDB represents a formal institutional extension of the BRICS as an informal club. Thus, the NDB serves as and will remain a test of the informal club culture of the BRICS because the establishment and finalization of its working details reflect the political resilience of the BRICS as an informal club. The declaratory statement at the Delhi BRICS statement outlined a "BRICS-led" South-South development bank with an initial fund of $\$ 50$ billion and a currency reserve agreement of $\$ 100$ billion to deal with any future financial crisis [BRICS, 2013]. But progress on the operational details was slow. The stakes were raised, severely testing the group's club culture: if they were to move from concept to delivery, they needed to agree on many sensitive and difficult issues.

Internally, the first major intra-BRICS challenge was to come up with a resolution on the distribution of resources. The BRICS members had ambivalent, if not somewhat diverging, positions on the funding proposal for the bank. Xu Qinghong, section chief of the Banking Supervision Department at the China Banking Regulatory Commission, noted, "There are vast differences between us ... Looking at the history of other multilateral institutions, I think such a feasibility study will take a long time and it may test our patience. Since the Delhi Summit, so far in China there have been a lot of doubts about a proposal" [Krishnan, 2012]. China's initial caution was also shared by Russia and Brazil, which kept a low profile when the idea of the bank was initially proposed.Indian officials up until the 2013 Durban Summit supported a plan to launch the fund with initial capital of $\$ 10$ billion, with equal contributions from each BRICS country [Sahu, 2013]. Brazil supported this proposal. However, with the advantage of massive international monetary reserves well beyond $\$ 3$ trillion, China pushed for an alternative modelwith contributions based on a country's financial capacity and an overall capital base of $\$ 100$ billion, which would allow China to contribute more to the capital base and thus have the advantage over the NDB's founding members. In contrast, in the context of preferring proportional contributions, Russia resisted setting any specific amount for capitalizing the bank at the Durban Summit. It was wary of obtaining advantages for its own national interest from the 
establishment of a new institution. Sergey A. Ryabkov, Russian deputy foreign minister, asserted that the BRICS declaratory statements about the bank were racing ahead of its practicalities [Wild, Galvao and Arkhipov, 2013].

The funding proposal reflects the underlying structural asymmetry in economic capacity among the BRICS members. Whereas a contribution of $\$ 10$ billion to the NDB was a small measure for China, which has a gross domestic product (GDP) larger than that of the four other BRICS members combined, raising such an amount for South Africa stood out as a serious test. For South Africa, $\$ 10$ billion comes up to $2.5 \%$ of its GDP. It only agreed to the terms because it considered the initiative a priority as a means of financing its own infrastructure projects and those promoted in the broader African continent more generally.

Furthermore, before the 2012 Tokyo meeting of BRICS finance ministers, Xu Qinghong expressed his concern that "non-economic factors" might hinder the bank's establishment. Indeed, non-economic factors lurked behind the intensive bargaining between China and India. China's stance often put India on the defensive and heightened the unequal power relationship between the two. There was speculation that China was willing to pay part of the shares of other BRICS members. This scheme could potentially help China take a leading role in safeguarding and advancing its own political agenda. From an Indian perspective, this would exacerbate its difficult working relations with China. India was concerned that China's leading role might eventually make the bank similar to the international financial institutions (IFIs) in terms of decision making, overshadowing other members' voting rights and interest [Russia Today, 2014]. It even explored the idea of opening up the bank's membership to advanced economies, so that they would receive minority stake (between $40 \%$ and $45 \%$ ) and China would not be able play overarching role with its financial power.

A second contentious issue was related to the location of the headquarters of the bank. China, India and South Africa all wanted to host the institution. Although this issue not a major source of debate at the outset, as the initiative slowly took shape it became amplified. The NDB's physical location could potentially give symbolic, if not real, advantage to the host country. India maintained the impression that it remained the inspirational force behind the bank. At Durban, Prime Minister Manmohan Singh said that the ideas of instituting a mechanism to recycle surplus savings into investments in devcos, first discussed at New Delhi, had been given a concrete shape [PTI, 2013]. Yet the assumption that the ideational inspiration should translate into physical ownership was not shared. On the one hand, a remark made by Jagannath Panda of the Institute for Defence Studies and Analyses was telling of India-China relations: "India sees the Brics as an economic proposition, while the Chinese see it as more political ... The Chinese are [initially] supporting heavily that the bank should be in South Africa, so they will have clout on that continent. India would still like to have the headquarters in India" [Mance, 2012]. On the other hand, South Africa, in accordance with China's initial interest, lobbied hard for this distinction, backed up not only on grounds of "in Africa" symbolism but also on the strength of South African financial institutions. China, however, later took the stand that the headquarters should be located in Shanghai, a position that was championed by its key think tanks. The Financial Research Center at Fudan University [2013, p. 65] argued after the New Delhi Summit that "China should strive to become the headquarters of the BRICS bank."

Such contestation about control spilled over into the discussions on what currency would be used in the bank's operations. The memorandum of agreement signed at New Delhi opened the way for BRICS members' development banks to extend loans denominated in their respective currencies. As mentioned above, this process of moving away from the U.S. dollar prompted speculation about Chinese control through the internationalized remimbi, especially as China had an incentive for advocating the use of its own currency to offset currency risks in 
development finance. Indian finance ministry officials were reported as expressing the view that the bank's goal had become a way to "legitimize" the use of Chinese currency overseas [Bagchi, 2012].

The final major bargaining rested on the mode of governance for the bank. Brazil wanted a lean structure like that of the Andean Development Corporation. On the lending provision, BRICS members remain divided on whether the bank will only lend to BRICS members or to non-members as well. China and South Africa want to open up the client base beyond the BRICS members. However, India wants a more concentrated focus and is wary of its own scarce capital being lent to other countries when its own needs are unmet. It has also raised questions about the criteria for loans. Internally, an equally significant line of interrogation surfaced about the role (or non-role) of civil society in the BRICS bank. Long-time critics of the lack of transparency and accountability have expressed concern about whether the BRICS bank would simply be "more of the same" [Oxfam Canada, 2014].

Despite the differences in preference, the BRICS members have shown great progress in finalizing the initial groundwork for the NDB. In Russian president Vladimir Putin's words: "BRICS Bank will be one of the major multilateral development finance institutions in this world" [Russia Today, 2014]. The informal club culture has allowed the BRICS members to work without any pressure of rigid institutional hurdles such as organizational problems, deadlines, influence from fragmented bureaucratic interest groups and turf fighting as witnessed within formal institutions.

\section{Conceptual Clarity: Testing the Club Dynamics of the BRICS and the NDB}

After six consecutive summits, the BRICS has emerged as a multilateral institution that has stable constitutive, regulative and procedural norms. Institutionally, however, it maintains the characteristics of an informal club model. This type of institutional arrangement demonstrates a club model when participation is restricted, members are privileged to act as agenda setters in policy making, exclusive goods are provided to members and the "club acts as the hub that irons out differences and illustrates how ... diversity does not entail divergence or conflict" [Tsingou, 2014, p. 232].

The BRICS's exclusivity is grounded both in the attribution of both internal and external status. Internally, members claim the "emerging power" status. The status attribution comes from peer recognition, which has positive and negative implications. It is positive because it reassures and reinforces the status among the members. At the same time, it can also be negative, because it demonstrates competitive ambition for geopolitical power. The status attribution within the club model also demonstrates how political such status attribution is when exclusivity raises questions about who is in and who is out. In the context of the composition of the BRICS, the critical questions are as follows: Why did South Africa gain membership but not also Nigeria? Why was Brazil included but not Mexico? Why was India added as a second Asian state but not also Indonesia? This selective component brings the politics of inclusion and exclusion to the fore. Thus, the international status of emerging power acts as an excludable good offered by the BRICS club to its members.

Externally, BRICS members transmit an international status beyond the club that is based on the narrative of South-South solidarity and performed through their leadership in representing the developing world. While members call for reform of the IFIs and the UN in the name of enhancing the representation of the global South, it is the BRICS members who are the first and biggest beneficiaries of status attribution institutionally. The gain from voting share reform 
either at the IMF or the World Bank will benefit the BRICS members and the giants within that group more than the broader global South. Thus the benefit from external status projection and status seeking is exclusively individual for the BRICS members while it is diffused for the wider global South.

At the same time, the BRICS provide outlet that benefits each member in addition to providing international status [Stuenkel, 2014]. Borrowing the words from Fen O. Hampson and Paul Heinbecker [2011], the BRICS is the "new" form of multilateralism that encompasses a type of power sharing that is not only "burden sharing," as in taking a leading role on the behalf of the entire Southern community, but also "benefit sharing" in international status through the collective claim of an ascendant leadership role by the club members. The BRICS's call for IMF reform is a significant case in point. BRICS members have been pushing for quota reform more vigorously since the 2008 global financial crisis. Brazilian finance minister Guido Mantega also called for reforming the IMF's principles for choosing directors and staff to make the recruiting process more inclusive. The communique issued by the BRICS finance ministers in 2011 articulates the rhetorical burden sharing of the global South:

We are concerned with the slow pace of quota and governance reforms in the IMF. The implementation of the 2010 reform is lagging. We must also move ahead with the comprehensive review of the quota formula by January 2013 and the completion of the next review of quotas by January 2014. This is needed to increase the legitimacy and effectiveness of the Fund. We reiterate our support for measures to protect the voice and representation of the IMF's poorest members [BRICS finance ministers, 2011].

In many cases, however, the symbolic political dimension is more powerful than its members' ability to translate its demands into tangible gains [Fourcade, 2013]. Although the BRICS has made reform of the IMF a central pillar of its club activities, no tangible sign of success has been achieved, with both the U.S. and European countries dragging their feet.

Since the introduction of the concept of the NDB, media analyses have painted two different pictures. On the one hand, one cluster of analyses hyped the BRICS project as a harbinger of a new world order where emerging powers advance their own agenda through institutional innovation while shunning the existing Bretton Woods institutions [Cohen and Arkhipov, 2013; Saidi, 2014; Pilling, 2014; Press TV, 2013]. On the other hand, another cluster questioned the institutional capacity of the BRICS to establish the NDB [Al Jazeera, 2013; Warner, 2012; Pavgi, 2012; Yardley, 2012]. Takehiko Nakao, president of the Asian Development Bank, pointed to the BRICS's capacity challenge in establishing the bank: "setting up banking business is not easy as it involves finding new projects, financing them and then monitoring the use of these funds and repayments" [Economic Times, 2013]. This bifurcated perspective challenged the BRICS members to translate the initiative from a declaratory one to one based on practice. With regard to Russia, A. A. Khryseva and E. V. Onikova [2013] argue that although NDB provides economic benefit for BRICS members, its successful development can also act as leverage for the BRICS countries individually in their negotiations vis-à-vis the North. As such, the NDB consolidated its position as the core test of cooperation and coordination among the BRICS members. From this perspective, the institutional stakes were high for the BRICS members to deepen the club culture in resolving mutual differences and finalize the bank. On the eve of the Durban Summit, remarks by South African president Jacob Zuma were telling in pointing to the BRICS's acceptance of the challenge:

BRICS is not a talk show. It is a serious grouping ... We are able to discuss things and take decisions. If, for example, we talk about the eminent establishment of a development bank, we discussed this a while ago and immediately charged our finance ministers to work on a modality. We are now ready to launch it [quoted in Chand, 2013]. 
Also, the NDB has become a symbolic challenge of the multilateral capacity of the BRICS for institutional innovation. Indeed, Guo Hongyu and Ren Weiwei [2014] argue that despite the uncertainty surrounding the bank, the BRICS's efforts are a breakthrough in the absence of the South's fair representation in international organizations. This is reflected by Indian prime minister Narendra Modi hailing the bank as a new chapter of cooperation for BRICS members [Zee News, 2014]. He noted that the bank and the contingent reserve arrangement demonstrate "our capacity to set up global institutions" [IANS, 2014]. Also, Brazilian president Dilma Rousseff said that "these initiatives show that, despite our diversity, our countries are committed to a solid and productive association" [quoted in AFP, 2014].

The challenge to finalizing the bank also became an extension of the collective capacity of the BRICS members to manage their financial, development and macroeconomic challenges. This is reflected in Putin's remark on the establishment of the bank:

There will be a very powerful means to prevent new economic difficulties in the world scenario and creating the bank will also establish the basis for huge macroeconomic changes ... [the bank] will allow us to undertake joint plans regarding our development [Lewis and Trevisani, 2014].

It also empowered the BRICS members to send a clear message to the international community that they are well capable of advancing alternative resolution unless the existing IFIs do not make progress in accommodating the demands of emerging powers. Indeed, at the launch of the NDB in Fortaleza, Rousseff declared, "It is a sign of the times, which demand reform of the IMF" [Soto and Boadle, 2014]. She said it proved the doubters were wrong: "even the most sceptical voices do recognise the contribution the Brics bloc of countries has provided in the field of international economics" [Smith, 2013]. As a symbolic status attribution of the emerging power of the BRICS members and their capacity to address their own needs, the NDB signals the West about their political demands. It further symbolizes strengthening cooperation in presence of mutual differences and isthus a powerful political incentive for the BRICS members to finalize it. It is no wonder that media analyst Mark Adamonis observed that "ten years ago the creation of such a bank would have been greeted with open derision and laughter in Washington, London, Paris, and other Western capitals. They're certainly not laughing anymore" [quoted in BRICS Post, 2014]. While many have argued that BRICS is all about symbolism and no substance, after the deepening of the BRICS in the Fortaleza David Pilling [2014] wrote that "it is indeed a minor miracle that five countries whose initials happen to form a catchy acronym have so quickly gone from Brics to a bricks-and-mortar bank."

\section{Conclusion}

From this examination, it is the application of the club model that underscores the ability of the BRICS to translate the idea of creating a bank of its own into substantive form. Building a culture that emphasised similarities and played down differences was a precondition to this breakthrough. This was especially so given not only the generalized context of internal differences among BRICS members, but also the specific dynamics of India's ideational entrepreneurship running up against Chinese interests and aspirations.

Yet, even faced with these constrains, the club culture held up and eased the delivery of the NDB. In terms of structure, there was a cost for India - and, for that matter, for other members with initial reservations. Once they were embedded in a self-selective, small-member club, with all the attributes of the rising big powers, there was a sense of entrapment, as the pressure of delivery for the club - to put mortar onto the BRICS - facilitated agreement, even when the results were asymmetric. Institutional status trumped the detailed results. 
Informal agency was a necessary ingredient. All of the countries had an incentive to play up their ability to work together, rather than to point accusatory fingers at one other. The fact that the Fortaleza host, Brazil, did not perceive itself to have the same stakes in the negotiations, buttressed this willingness to accent the positive outcome.

Finally, the complex details involved in setting up the NDB allowed logrolling to be a major factor. The image of China winning in getting the headquarters was countered by the distribution of benefits more widely among the BRICS members. And any legacy of defeat for India was mitigated by the particular political circumstances, in which any blame could be directed at the previous government of Singh rather than at the new Modi government.

To highlight the benefits of the club model is not to downplay the internal problems of the BRICS in establishing the NDB. The NDB is a formal institution, in many ways at odds with the informal club culture of the BRICS. In institutional terms, as suggested by the struggle over the location of the headquarters of the NDB, this formality will inevitably bring out different and arguably more intense conflicts about rules of procedure. These sensitivities will in turn be exacerbated by the bank's actual practices, including the range of recipients.

That being said, the informal club model has provided a good fit for the BRICS. In the initial test case, the BRICS countries were successful in using the club model to navigate frictions, with a great deal of flexibility and resilience in building cooperation through a specific, instrumental and highly visible initiative. For a group that has been commonly cast as more concerned about status than results, this is considerable achievement, and creates an image of a new and loose form of multilateralism.

\section{References}

Abdenur A.E. (2014) China and the BRICS Development Bank: legitimacy and multilateralism in South South cooperation. IDS Bulletin 45(4), pp. 85-101. doi: 10.1111/1759-5436.12095.

AFP (2014) BRICS Development Bank launched, first president to be from india. Times of India, 17 July. Available at: http://timesofindia.indiatimes.com/business/international-business/BRICS-DevelopmentBank-launched-first-president-to-be-from-India/articleshow/38440605.cms (accessed 1 May 2015).

Al Jazeera (2013) "BRICS nations fail to launch new bank." 28 March. Available at: http://www.aljazeera.com/ news/africa/2013/03/2013327145258420830.html (accessed 1 May 2015).

Alden C. and M. Schoeman (2013) South Africa in the company of giants: the search for leadership in a transforming global order. International Affairs 89(1), pp. 111-29. doi: 10.1111/1468-2346.12007.

Armijo L.E. (2007) The BRICS countries (Brazil, Russia, India and China) as analytical category: mirage or insight? Asian Perspective 31(4), pp. 27-42. Available at: http://www.brics.global.wisc.edu/v31n4-a.pdf (accessed 1 May 2015).

Armijo L.E. and S.W. Burges (2009) Brazil, the Entrepreneurial and Democratic BRIC. Polity 42(1), pp. $14-$ 37. doi: dx.doi.org/10.1057/pol.2009.15.

Bagchi I. (2012) BRICS summit: member nations criticizes the West for financial mismanagement. Times of India, 30 March. Available at: http://timesofindia.indiatimes.com/india/BRICS-summit-Member-nationscriticizes-the-West-for-financial-mismanagement/articleshow/12462502.cms (accessed 1 May 2015).

Baldwin D.A. (1985) Economic statecraft. Princeton NJ: Princeton University Press.

Balogh T. (1967) Multilateral v. bilateral aid. Oxford Economic Papers 19(3), pp. 328-44. doi: $10.2307 / 2662330$.

Barnett M. and M. Finnemore (1999) The Politics, Power, and Pathologies of International Organizations. International Organization 53(4), pp. 699-732.

Brawley M.R. (2007) Building blocks or a BRIC wall? Fitting U.S. foreign policy to the shifting distribution of power. Asian Perspective 31(4), pp. 151-75. 
BRICS (2013) "Media note on the informal meeting of BRICS leaders ahead of the G20 summit in St. Petersburg.” St. Petersburg, 5 September. Available at: http://www.brics.utoronto.ca/docs/130905-note.html (accessed 1 May 2015).

BRICS finance ministers (2011) “BRICS finance ministers' joint communiqué." Washington DC, 22 September. Available at: http://www.brics.utoronto.ca/docs/110922-finance.html (accessed 1 May 2015).

BRICS Post (2014) Shanghai to host BRICS bank: Putin aide. 11 July. Available at: http://thebricspost.com/ shanghai-to-host-brics-bank-putin-aide/\#.VUVn7dpViko (accessed 1 May 2015).

Brütsch C. and M. Papa (2013) Deconstructing the BRICS: bargaining coalition, imagined community, or geopolitical fad? The Chinese Journal of International Politics 6(3), pp. 299-327. doi: 10.1093/cjip/pot009.

Chand M. (2013) BRICS bank dream set to turn real, power games begin. Russia and India Report, 26 March. Available at: http://in.rbth.com/politics/2013/03/26/brics_bank_dream_set_to_turn_real_power_games_ begin_23217.html (accessed 1 May 2015).

Chen Z. (2014) Jin zhuan guojia kaifa yínhang dui zhongguo jīnrong chuangxin de zhu yi fenxi [Benefit analysis of the BRICS development bank for Chinia's financial innovation]. Finance and Accounting for International Commerce (12).

Chin G.T. (2014) The BRICS-led Development Bank: Purpose and Politics beyond the G20. Global Policy 5(3), pp. 366-73. Available at: http://dx.doi.org/10.1111/1758-5899.12167. doi: 10.1111/1758-5899.12167.

Christensen S.F. (2013) Brazil's Foreign Policy Priorities. Third World Quarterly 34(2), pp. 271-86. doi: 10.1080/01436597.2013.775785.

Cohen M. and I. Arkhipov (2013) BRICS nations plan new bank to bypass World Bank, IMF. Bloomberg, 26 March. Available at: http://www.bloomberg.com/news/articles/2013-03-25/brics-nations-plan-new-bankto-bypass-world-bank-imf (accessed 1 May 2015).

Easterly W. and T. Pfutze (2008) Where does the money go? Best and worst practices in foreign aid. Journal of Economic Perspectives 22(2), pp. 29-52. doi: 10.1257/jep.22.2.29.

Economic Times (2013) Setting up BRICS bank not going to be easy: Takehiko Nakao. 3 May. Available at: http://articles.economictimes.indiatimes.com/2013-05-03/news/39009243_1_brics-countries-developmentbank-sustainable-development-projects (accessed 1 May 2015).

Ferdinand P. (2014) Rising powers at the UN: an analysis of the voting behaviour of BRICS in the General Assembly. Third World Quarterly 35(3), pp. 376-91. doi: 10.1080/01436597.2014.893483.

Financial Research Center F. U. (2013) Will the BRICS Development Bank settle in Shanghai? China Watch 2013, pp. 63-65. Available at: http://www.shanghaiforum.fudan.edu.cn/index.php?c=publication\&a=list\&ty peid=10027 (accessed 1 May 2015).

Fourcade M.(2013)Thematerialandsymbolic construction ofthe BRICs: Reflectionsinspiredbythe RIPESpecial Issue. Review of International Political Economy 20(2), pp. 256-67. doi: 10.1080/09692290.2013.779408.

Glosny M.A. (2009) China and the BRICs: a real (but limited) partnership in a unipolar world. Polity 42(1), pp. 100-29. doi: dx.doi.org/10.1057/pol.2009.14.

Gray K. and C.N. Murphy (2013) Introduction: rising powers and the future of global governance. Third World Quarterly 34(2), pp. 183-93. doi: 10.1080/01436597.2013.775778.

Guo H. and W. Ren (2014) The BRICS bank: new silk road for financial cooperation. People Tribune 18.

Hampson F.O. and P. Heinbecker (2011) The 'new' multilateralism of the twenty-first century. Global Governance 17(3), pp. 299-310.

Hancock K.J. (2007) Russia: great power image versus economic reality. Asian Perspective 31(4), pp. 71-98.

Hawkins D.G., D.A. Lake, D.L. Nielson and M.J. Tierney, eds. (2006) Delegation and agency in international organizations. Cambridge UK: Cambridge University Press.

Huang Y. (2011) The myth of economic complementarity in Sino-Indian relations. Journal of International Affairs 64(2), pp. 111-24. 
IANS (2014) “Agreement on BRICS development bank significant step: Modi.” Times of India, 16 July. Available at: http://timesofindia.indiatimes.com/india/Agreement-on-BRICS-development-bank-significant-stepModi/articleshow/38441788.cms (accessed 1 May 2015).

Ikenberry G.J. (2001) After victory: institutions, strategic restraint, and the rebuilding of order after major wars. Princeton: Princeton University Press.

Keohane R.O. (1990) Multilateralism: an agenda for research. International Journal 45(4), pp. 731-64. doi: $10.2307 / 40202705$.

Keohane R.O., S. Macedo and A. Moravcsik (2009) Democracy-enhancing multilateralism. International Organization 63(1), pp. 1-31. doi: doi:10.1017/S0020818309090018.

Khryseva A.A. and E.V. Onikova (2013) Problemy i perspektivy razvitiya rossiyskoy ekonomiki v ramkakh ob'yedineniya BRIKS [Problems and prospects of economic development of Russia as a participant of BRICS]. Volgograd State Technical University Journal 16(11), pp. 39-43.

Koremenos B., C. Lipson and D. Snidal (2001) The rational design of international institutions. International Organization 55(4), pp. 761-99. doi: 10.1162/002081801317193592.

Krishnan A. (2012) China's caution may slow BRICS bank plan. The Hindu, 10 October. Available at: http:// www.thehindu.com/business/Economy/chinas-caution-may-slow-brics-bank-plan/article3985250.ece (accessed 1 May 2015).

Kurlantzick J. (2007) Charm offensive: how China's soft power is transforming the world. New Haven CT: Yale University Press.

Leksyutina Y. (2014) Kitay v BRIKS: motivatsiya uchastiya. World Economy and International Relations [China in the BRICS: the motivation of participation] (4), pp. 81-89.

Lewis J.T. and P. Trevisani (2014) Brics agree to base development bank in Shanghai. Wall Street Journal, 15 July. Available at: http://www.wsj.com/articles/brics-agree-to-base-development-bank-in-shanghai1405453660 (accessed 1 May 2015).

Mance H. (2012) Global shift: a bank of and for the BRICS is in the air. Financial Times, 12 September.

Mansingh S. (2010) Assessing reorientation of India's foreign policy in a globalized world. International Studies 47(2-4), pp. 143-61. doi: 10.1177/002088171104700406.

Mearsheimer J.J. (1994/95) The false promise of international institutions. International Security 19(3), pp. 5-49. Available at: http://mearsheimer.uchicago.edu/pdfs/A0021.pdf (accessed 1 May 2015).

Milner H.V. and D. Tingley (2013) The choice for multilateralism: foreign aid and American foreign policy. Review of International Organizations 8(3), pp. 313-41. doi: 10.1007/s11558-012-9153-х.

Nielson D.L. and M.J. Tierney (2003) delegation to international Organizations: Agency Theory and World Bank environmental reform. International Organization 57(2), pp. 241-76. doi: 10.2307/3594852.

Otter M. (2003) Domestic public support for foreign aid: does it matter? Third World Quarterly 24(1), pp. 115-25. doi: $10.2307 / 3993633$.

Oxfam Canada (2014) "The new BRICS bank should offer a new vision for development, not more of the same." 15 July. Available at: http://oxfam.ca/news/new-brics-bank-should-offer-new-vision-for-development (accessed 1 May 2015).

Pang Z. (2014) Develop a non-western global governance scheme: the BRICS cooperation and transformation of world order. People Tribune.

Pavgi K. (2012) BRICS not ready for joint development bank. World Politics Review, 10 April. Available at: http://www.worldpoliticsreview.com/articles/11825/brics-not-ready-for-joint-development-bank (accessed 1 May 2015).

Pilling D. (2014) The Brics bank is a glimpse of the future. Financial Times, 30 July. Available at: http://www. ft.com/intl/cms/s/0/f7b876a0-170e-11e4-b0d7-00144feabdc0.html\#axzz3Z1man9uE (accessed 1 May 2015).

Press TV (2013) “New BRICS bank to rival World Bank, IMF.” 26 March. Available at: http://www.presstv.ir/ detail/2013/03/26/295322/new-brics-bank-to-rival-world-bank-imf/ (accessed 1 May 2015). 
PTI (2013) BRICS agrees to create $\$ 100$ bn contingency fund. Economic Times, 27 March. Available at: http:// articles.economictimes.indiatimes.com/2013-03-27/news/38070645_1_contingency-reserve-arrangementbrics-development-bank-brics-summit (accessed 1 May 2015).

Roberts C. (2009) Russia’s BRICs diplomacy: rising outsider with dreams of an insider. Polity 42(1), pp. 38-73. doi: dx.doi.org/10.1057/pol.2009.18.

Ruggie J.G. (1992) Multilateralism: the anatomy of an institution. International Organization 46(3), pp. 56198. doi: 10.1017/S0020818300027831.

Ruggie J.G., ed. (1993) Multilateralism matters: the theory and praxis of an institutional form. New York: Columbia University Press.

Rusko C.J. and K. Sasikumar (2007) India and China: from trade to peace? Asian Perspective 31(4), pp. 99123.

Russia Today (2014) “BRICS establish \$100bn bank and currency pool to cut out western dominance.” 15 July. Available at: http://rt.com/business/173008-brics-bank-currency-pool/ (accessed 1 May 2015).

Sahu P. (2013) BRICS nations broadly agree on capital structure of bank. Wall Street Journal, August.

Saidi N.H. (2014) The BRICS bank signals the end of the American financial empire and U.S. dollar hegemony. World Post, 21 July. Available at: http://www.huffingtonpost.com/dr-nasser-h-saidi/the-brics-bank-signalsth_b_5604294.html (accessed 1 May 2015).

Sharma R. (2012) Broken BRICS: why the rest stopped rising. Foreign Affairs 91(6), pp. 2-7. Available at: https://www.foreignaffairs.com/articles/brazil/2012-10-22/broken-brics (accessed 1 May 2015).

Smith D. (2013) Brics eye infrastructure funding through new development bank. Guardian, 28 March. Available at: http://www.bloomberg.com/news/articles/2013-03-27/brics-approve-currency-fund-as-bankstart-up-stalls (accessed 1 May 2015).

Soto A. and A. Boadle (2014) BRICS set up bank to counter western hold on global finances. Reuters, 16 July. Available at: http://in.reuters.com/article/2014/07/15/brics-summit-bank-idINKBN0FK08620140715 (accessed 1 May 2015).

Stephens P. (2011) A story of Brics without mortar Financial Times, 24 November. Available at: http:// www.ft.com/intl/cms/s/0/352e96e8-15f2-11e1-a691-00144feabdc0.html?siteedition=intl\#axzz3TH6th0nf (accessed 1 May 2015).

Stuenkel O. (2014) Emerging powers and status: the case of the first BRICs summit. Asian Perspective 38(1), pp. 89-109. doi: 10.5555/0258-9184-38.1.89.

Tsingou E. (2014) Club governance and the making of global financial rules. Review of International Political Economy 22(2), pp. 225-56. doi: 10.1080/09692290.2014.890952.

Vieira M.A. and C. Alden (2011) India, Brazil, and South Africa (IBSA): South-South cooperation and the paradox of regional leadership. Global Governance 17(4), pp. 507-28. doi: 10.5555/1075-2846-17.4.507.

Warner J. (2012) Why a Brics-built bank to rival the IMF is doomed to fail. Telegraph, 29 March. Available at: http://www.telegraph.co.uk/finance/financialcrisis/9173668/Why-a-Brics-built-bank-to-rival-the-IMF-isdoomed-to-fail.html (accessed 1 May 2015).

Wild F., A. Galvao and I. Arkhipov (2013) BRICS approve currency fund as bank start-up stalls. Bloomberg, 27 March. Available at: http://www.bloomberg.com/news/articles/2013-03-27/brics-approve-currency-fundas-bank-start-up-stalls (accessed 1 May 2015).

Yardley J. (2012) BRICS leaders fail to create rival to World Bank. New York Times, 29 March. Available at: http://www.nytimes.com/2012/03/30/world/asia/brics-leaders-fail-to-create-rival-to-world-bank.html (accessed 1 May 2015).

Ye Y. (2014) Jin zhuan guojia yingji chubei anpai qianzhan. WOrld Economy Study [The prospect for BRICS Contingent Reserve Arrangement], p 3.

Zee News (2014) PM Modi hails BRICS bank, promises to work closely with South America. 17 July. Available at: http://zeenews.india.com/news/nation/pm-modi-hails-brics-bank-promises-to-work-closely-with-southamerica_947992.html (accessed 1 May 2015).

Zhu J. (2014) BRICS cooperation mechanism in transition. International Observer, p. 3. 